International JOURNAL OF MULtidisciplinaRy Research AND ANALysis

ISSN(print): 2643-9840, ISSN(online): 2643-9875

Volume 03 Issue 12 December 2020

DOI: 10.47191/ijmra/v3-i12-12, Impact Factor: 5.522

Page No.- 339-340

\title{
Modern Requirements for a Music Teacher General Educational School
}

\author{
K.S. Bobokulov ${ }^{1}$, A. M. Abdurakhimov ${ }^{2}$ \\ ${ }^{1}$ Senior Lecturer, Department of Musical education of the "Faculty of Art" Jizzakh State Pedagogical Institute \\ Jizzak, Uzbekistan \\ ${ }^{2}$ Lecturer, Department of Musical education of the "Faculty of Art" Jizzakh State Pedagogical Institute \\ Jizzak, Uzbekistan
}

Abstract: In the implementation of the complex socio-pedagogical task - the upbringing of a qualitatively new person of the future, an important role is assigned to the teacher.

Keywords: School, music, modern requirements, the personality of the teacher.

\section{Introduction}

The personality of the teacher, the improvement of everything, the search for new solutions, the development of modern scientific thinking by him are important components of an effective teaching and educational process in secondary school.

The teaching profession is one of the most ancient and is considered to be very responsible and difficult. In the writings of thinkers of the past, attention is constantly focused on the fact that a person who has chosen a fetish, a mentor of a teacher, should not only love children, have an interest, a predisposition to this profession, but also be literate and prepared.

\section{The main results and findings}

The ancient Greek philosopher Confucius drew attention to the high level of teacher training and his pedagogical wisdom. "When a noble husband teaches and educates, he leads, but does not pull with him, encourages, but does not force, shows the way, but allows the student to go on his own." The content, methods and requirements for teacher training have been improved over many generations by teachers - "practitioners and teachers - theorists. The range of issues, the level of abilities, the corresponding amount of knowledge and experience necessary for the teaching profession were determined. Over time, the concept of" preparedness "," focus ", "Readiness" for teaching activities were transformed into a new, more modern category "professional competence".

Time makes new demands on the professional skills of a music teacher. Questions about that. how a teacher should beat, what qualities a teacher should have in order to be at the level of modern requirements, are widely discussed in print today. Characterizing the personality of a music teacher, L. G. Archazhnikova notes its integrity: "The most important manifestation of integrity is the choice of the main line of behavior by a person, determination of opportunities and the kind of activity in which she can most clearly express herself. An integral personality expresses itself in a striving for creativity, for artistic self-manifestation. "

Among the professionally significant qualities of the personality of a music teacher, we especially emphasize the observant! $b$, the ability and ability of the teacher to penetrate the inner world of students, to adequately perceive their feelings and thoughts at the moment of perception of music. Perception is one of the central problems of musical education of students E.B. Abdullin emphasized that: "... the process of music perception includes the life and musical experience of schoolchildren, which belongs to a wider sphere of musical phenomena. This is both the experience of direct experience and reflection, formed under the influence of musical art, and artistic experience associated with the use of music ".

An experienced teacher, by insignificant external manifestations - cues, facial expressions and manifestations of the psychological state of the student - joy, sadness, indifference - can correctly understand the state of mind of the student. 


\section{Modern Requirements for a Music Teacher General Educational School}

Therefore, it is the perceptual information that comes through the "feedback channel" during the perception of music or during the story about it, which gives the teacher the material that is necessary to regulate the educational process. Psychologically correct assessment of only short-term experiences of students is completely insufficient for music lessons. It is necessary to study children in depth systematically. Therefore, in the system of new approaches in solving teaching and educational problems, a music teacher must necessarily include his ability and ability to study students. A modern music teacher must also have didactic qualities. This is the ability and ability to creatively carry out the processing of scientific and methodological material into the material of an academic subject available to students; the ability to apply and develop new active methods that meet the characteristics of the class, their general and musical culture; specific conditions for conducting classes; depending on a particular situation - adjust your activities; accustom students to independent work and others.

One of the most important elements of the didactic ability that a music teacher must possess is the ability to manage his speech. In the context of a music lesson, singing songs, listening to musical works, playing children's musical instruments and other activities of students should be accompanied by the teacher's story. On this occasion, L. G. Archazhnikova notes; “In order for the performance to be understandable for students, stimulate the emergence of figurative associations, contribute to the logical comprehension of what was listened to, it is necessary to bring them to active listening, teach them how to live and music. Verbal commentary serves to fulfill this sadani. "In this regard, a music teacher must constantly work on his speech, acquire the ability to speak not only competently, but also figuratively, expressively, emotionally. After all, the field of activity of the teacher of ethical education (lectures, concerts, talks about composers, etc.), and their success depends to a large extent on the teacher's oratorical data.

In essence, the activity of a music teacher should be structured like this. So that in practice there is a contradiction between the acquired leading scientific and methodological knowledge and practical skills. It is this contradiction that will force the teacher to pay attention to self-education and self-development, which are one of the most important areas of enhancing the educational process. A seeking music teacher strives to achieve success, primarily by increasing the effectiveness of his musical and pedagogical activities. To achieve high efficiency of his actions, a music teacher must:

$\checkmark$ know the scientific foundations of the educational process, methods and means of influencing students;

$\checkmark$ know the psychology of the student, the level of his general and intellectual abilities;

$\checkmark$ know the individual characteristics of musical abilities and performance training;

$\checkmark$ be able to analyze and creatively interpret special professional literature;

$\checkmark$ be able to plan your musical and pedagogical activity in a holistic musical and pedagogical process; improve your teaching skills.

It should be noted that the implementation of each of these components is due to the need for the teacher-musician to develop self-reflection, introspection, self-esteem, which allow not only objectively investigated, at the personal level of their abilities, but also determine the ways of their development.

\section{Conclusion}

Thus, the upbringing of independence, initiative, and the need for creative work is the basis of the psychological and practical preparation of a music teacher for self-education. The main indicators of personality development are erudition, independence of mind, ability and others.

Also, an important condition for the self-development of the personality of a teacher-musician is the organization of their own activities, stimulating potential and actual opportunities and abilities. So, the activity of a music teacher consists not only of theoretical and practical training, but also largely depends on his own personal qualities, on the ability to independently acquire and update knowledge, to develop the need for self-improvement and creative search for forms of implementing his activities.

\section{References}

1) Averyanov A.N. Systemic knowledge of the world: methodological problems. - M.: Politizdat, 1985.-- 263 p.

2) Babansky Yu.K. Intensification of the educational process. "Knowledge" - M., 1987, 79 p.

3) Pushkareva EA Knowledge as the basis of science and education: the specifics of the current state. Philosophy of education. - 2007. - No. 3. - p. 31-35.

4) Formation of systems thinking in teaching: Textbook for universities / Ed. Z.A. Reshetova. - M.: UNITI-DANA, 2002.-344 p. 